\title{
Section 4 of the Muslim Family Laws Ordinance, 1961: A Critic
}

Introduction

Professor Dr. A.W.M Abdul Huq ${ }^{*}$

Law, whether divine or manmade, is always for the well-being of the human beings. In other words, laws are ultimately related to life experiences which are not a monopoly of the theologians only. ${ }^{1}$ As the society is not any constant phenomenon, it inevitably changes every moment. As a result laws are needed to be changed in compliance with the changing demands of the society. In Islamic Legal System as well the iron fist of taqlid (the doctrine of imitation) had to give way to ijtihad (meaning independent and free exercise of intellect to interpret interpretation of Islamic laws). It is always open for and permitted to, the thinkers, lawmakers and the rulers who are entrusted to apply shariah in society. In this short commentary I intend to address a particular issue relating to the orphaned children's inheritance right. This is an extremely practical anomaly of the Doctrine of Representation usually escaping our notice.

\section{Grandchild's inheritance right: the Islamic Law}

The Islamic law of inheritance does not all together deny the grandchild of the propositus their right to inheritance. Sunni Law places them in the list of quranic sharers. Unless excluded otherwise, they inherit from their grandparent. The doctrine of representation comes into question in case of allotment of their shares. The doctrine is accepted at least for two purposes: ${ }^{2}$

\section{A) For the purpose of determining who are entitled to inherit}

However while using the doctrine of representation for the purpose of determining who are entitled to inherit, the principle of exclusion (nearer in degree excluding the remote) is not curtailed or suspended. Thus if A dies leaving him surviving a son and grandsons by a predeceased son, the grandsons are excluded from inheritance by their uncle. They do not take in their father's stead though he would have been an heir had he survived his father. This is true in Shia and Sunni Law alike.

B) For the purpose of determining the share of the heirs

\footnotetext{
* Dean, Faculty of Law, Northern University Bangladesh (NUB), Dhaka.

${ }^{1}$ Report of Pakistan Commission on Marriage and Family Laws, $20^{\text {th }}$ June, 1956.

${ }^{2}$ M. Hedyatullah and Arshad Hedayatullah (Ed), Mulla's Principles of Mahomedan Law, $19^{\text {th }}$ Edition, Tripathi, 1990, Para 93(1) at p 85
} 
But if both sons predeceased the propositus who died leaving three grandsons by one son and two by the other then all the grandsons are heirs. In that case, the principle of representation is applied in Shia Law for the purpose of ascertaining the share of each grandson. If the principle is applied, the estate of the propositus shall be distributed per stripes among the grandchild. The grandsons of one branch will have to divide into three what the grandsons of other branch will divide in half. However Sunni Law does not recognize representation in that case. The five grand sons shall inherit per capita in their own rights as heirs of the propositus, not as the representatives of the predeceased son or daughter. ${ }^{3}$

\section{Addressing an apparent injustice: the 1961 Reform}

Being excluded by heirs of nearer degree, as shown above, the orphaned grandchild become economically and socially vulnerable. So all over the Muslim world the jurists thought and tried to solve this problem, using different devices, intending to preserve the interest of the orphaned grandchildren in the property of the propositus. To this end, a new sort of doctrine of representation was adopted in Pakistan in 1961. The Government of Pakistan promulgated the Muslim Family Laws Ordinance (hereinafter MFLO) in 1961 touching some of the substantive Islamic personal law issues. Section 4 of the Ordinance reads as follows:

In the event of death of any son or daughter of the propositus before the opening of succession, the children of such son or daughter, if any, living at the time the succession opens, shall per stripes, receive a share equivalent to the share which such son or daughter, as the case may be, would have received if alive.

Thus it is clear that Section 4 of the MFLO, 1961 has accommodated the doctrine of representation by suspending the rule of nearer excluding the remote. It has also incorporated into Sunni Law, the Shia concept of stirpital succession. Now the orphaned grand children are per stripes allotted the share which their deceased parents would have taken had he or she survived the propositus.

\section{Anomalies of Section 4: Pakistani approach}

This accommodation of stirpital succession has caused some anomalies with which the Courts in Pakistan had to deal with at least in three cases.

\section{Mst. Zarina Jan v. Mst. Akbar Jan PLD 1975 Peshawar 252}

\footnotetext{
${ }^{3}$ Syed Amir Ali, Mahomedan Law, Vol II, $5^{\text {th }}$ Edition, 1985 Reprint, Himalayan Books, New Delhi, p. 132-134
} 
In Mst. Zarina Jan, the propositus Shah Zaman left one daughter Mst. Akbar Jan and one predeceased son Mir Afzal's daughter Mst. Zarina Jan. There was no dispute that Mir Afzal and Mst. Akbar Jan would inherit 2/3 and 1/3 of the property respectively. The controversy was whether the whole of Mir Afzal's share would go to his only daughter Zarina Jan or not. To put it in the alternative, the question was whether Mir Afzal's Sister Akbar Jan would also inherit from him according to the Shariat or not. The problem may be presented through a graphical presentation:

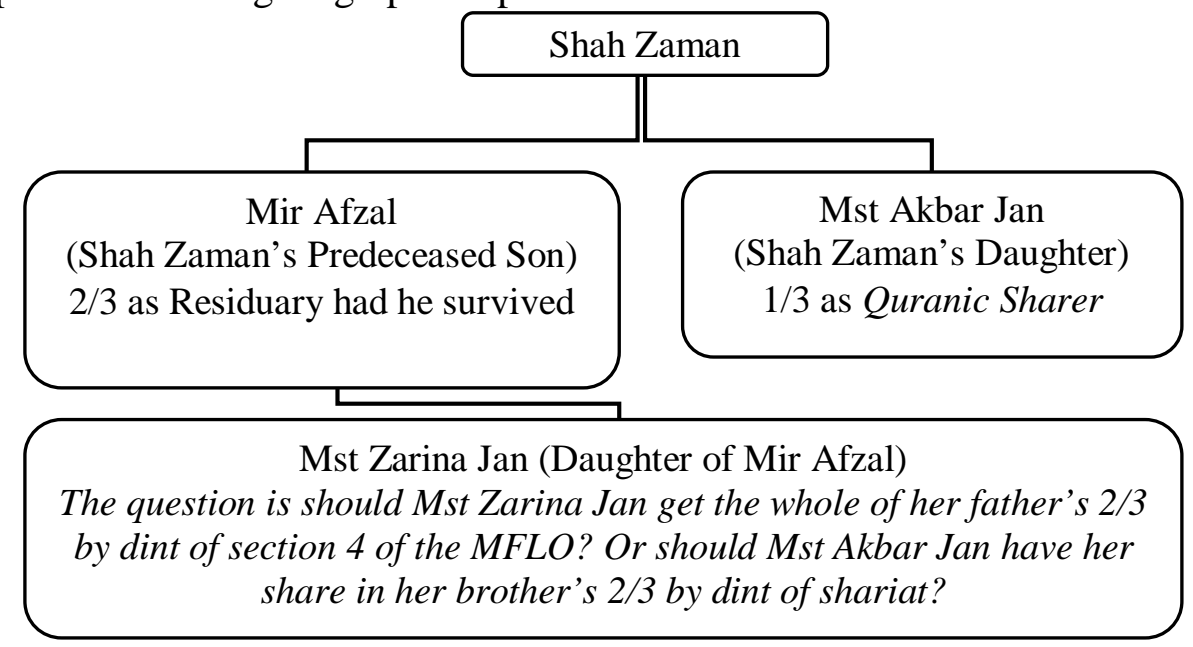

The lower Appellate Court held:

Section 4 of the Muslim Family Laws Ordinance, 1961 has given a right to the heirs of a pre-deceased son to inherit the share of their father in the property of their grand father. This section has not ousted the application of Shariat in other matters of inheritance and it has just given a right to the heirs of a pre-deceased son to inherit the share of their father in the property of their grandfather. Thus Shariat will apply to the inheritance of Mir Afzal, father of Mst Zarina Jan. ${ }^{4}$

In other words Mst Zarina Jan would inherit $1 / 2$ of the $2 / 3$ of the estate to which her father Mir Afzal was entitled and the other half would go to Mst Akbar Jan, the sister of Mir Afzal. At the end the gross allocation shall be: Mst Zarina Jan would get $1 / 2$ of $2 / 3=1 / 3$ and Mst Akbar Jan would get $1 / 2$ of $2 / 3$ plus $1 / 3=2 / 3$ of the property. However, the Peshawar High Court

${ }^{4}$ PLD 1975 Peshawar 252, at 253 
reversed the decision by giving Mst Zarian Jan the whole of her father's share and depriving Mst Akbar Jan from any share in her deceased brother It held:

Under the Ordinance Mst. Zarina daughter of Mir Afzal is entitled to inherit the same share to which her father Mir Afzal was entitled in the inheritance of his father Shah Zaman. The reason is that the Ordinance by adopting the principle of per stripes distribution of inheritance meant to keep intact the share of the predeceased son or daughter to be inherited by his son or daughter according to it, the heirs of the predeceased issue will inherit from propositus what their predecessor-in-interest would have inherit.... The impugned interpretation militates against the letter and spirit of Section 4 of the Ordinance which could not be the intention of the Law makers. ${ }^{5}$

\section{Kamal Khan v. Mst Zainab PLD 1983 Lahore 546}

In Kamal Khan the Lahore High Court dissented from the above view of Peshawar High Court. The fact of the case may be presented as follows:

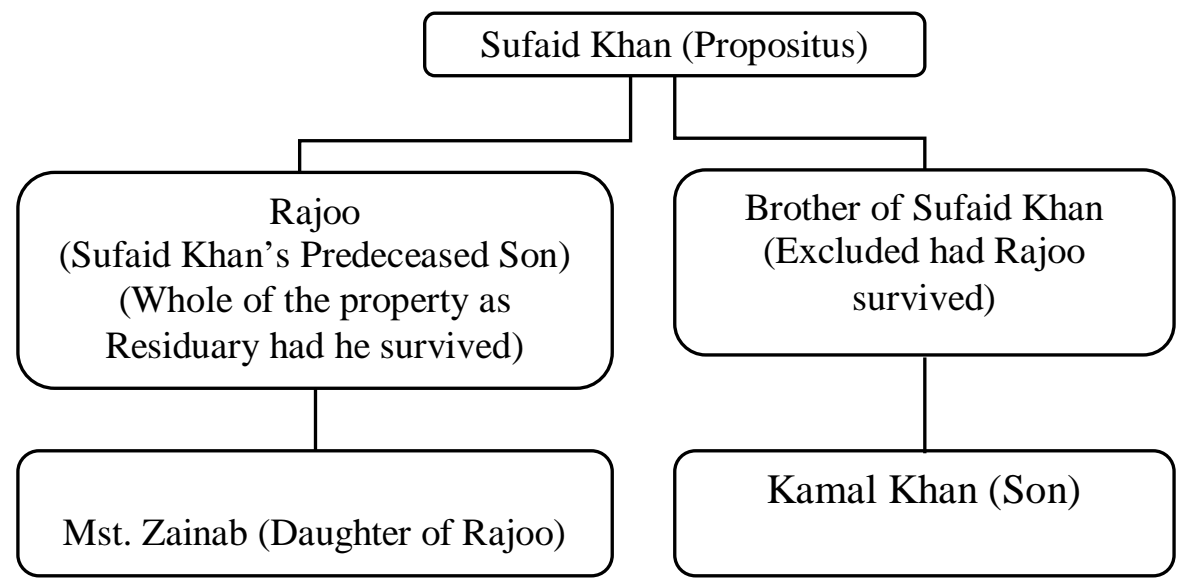

The Lahore High Court explained the philosophy behind Section 4 of the MFLO, 1961:

The starting point is, that notionally the off spring of the propositus is deemed to be alive for the purpose of succession, at the time of the death of the propositus, and the succession of the grandchild is to be calculated again notionally as if the parent of the grandchild died after the death of the original propositus. ${ }^{6}$

${ }^{5} 1975$ Peshawar 252 p. 253-254

${ }^{6}$ PLD 1983 Lahore 546 at 548 
Thus Rajoo would inherit the entire estate of Sufaid Khan as being his only son and Zainab would inherit half of Rajoo's estate and the remaining half would revert to the nearest agnate Kamal Khan. According to the Peshawar decision Zainab would have inherited the entire estate of her Grandfather.

\section{Farid v. Manzooran PLD 1990 SC 511}

The Pakistani Supreme Court took note of the matter in. the table of this case may be as follows:

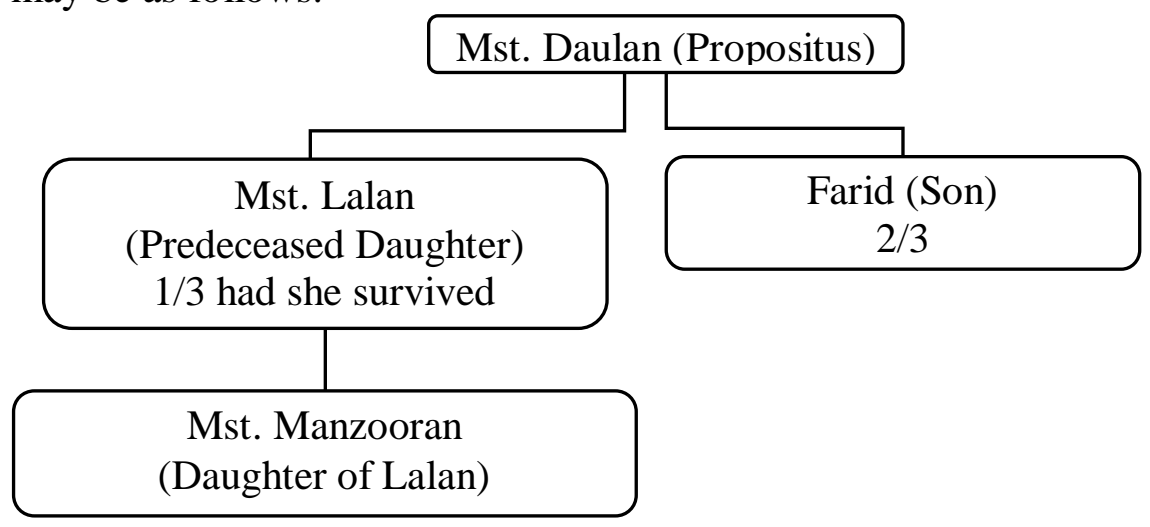

At the time of the opening of the inheritance of Mst. Daulan her predeceased daughter Mst. Lalan would be taken as living under section 4 of the MFLO and accordingly she would get $1 / 3$ of the inheritance, $2 / 3$ going to Mst Daulan's son Farid. The question is whether or not Mst. Lalan's daughter Mst Manzooran will get whole of the estate of Mst. Lalan. According to the judgment of the Lahore High Court, Mst. Manzooran would get one half of the estate, the other half going to the reversionaries including Farid but according to that of the Peshawar High Court, she will take the whole of the estate of her deceased mother.. So the issue before the Supreme Court was:

Whether it was not the intention of law-making in section 4 of the Family Laws Ordinance, 1962, to provide an opportunity of obtaining only Islamic law shares, to the children of the predeceased son or daughter of the propositus and that intention was not to increase their Islamic Law shares. ${ }^{7}$

The Pakistani Supreme Court confirmed the Lahore High Court decision of Kamal Khan v. Zainab and held that Section 4 could not be construed against

\footnotetext{
${ }^{7}$ A.M. Serajuddin, Shariah Law and Society, Tradition and Change in the Indian
} Subcontinent, Asiatic Society of Bangladesh, 1999, p. 102 
the interest of other heirs of the deceased who were entitled to share the inheritance under the rules of Muslim Law of inheritance. ${ }^{8}$

\section{Critics of the Pakistan Supreme Court}

Dr Lucy Carrol finds the Peshawar decision preferable to that of Lahore. She questions the hypothesis of Lahore High Court:

The Ordinance does not say that the orphaned grandchild will receive that share of the grandparent's estate to which he would be entitled (1) on the assumption that the predeceased parent had been alive at the time of the grandparent's death, and (2) on the further assumption that the predeceased parent had then died leaving his notional share of the grandparents' estate to be distributed among his heirs. ${ }^{9}$

To Carroll, as the purpose of the legislation is to improve the position of orphaned grandchild, it is hardly surprising that she would receive a larger share than she would have received under the traditional law. ${ }^{10}$ Dr. Alamgir Muhammad Sirajuddin also is not wondered to see that in the prevailing 'mood of conservatism' the Pakistan Supreme Court would confirm the Lahore decision in 1990 and 'strike at the root of Section 4'. ${ }^{11}$

\section{Defending the Pakistan Supreme Court's stance}

It is submitted, however, that the critics of the Pakistan Supreme Court have overlooked at least two seriously important points. On substantial grounds, I support the Pakistan Supreme Court and recommend the adoption of it in the MFLO, 1961.

Firstly, section 4 may be seen as a sort of insurance for the orphaned grandchildren. It is a cardinal principle of law of insurance that under no circumstances the insured is allowed to benefit more than the loss suffered by him. This is because, if that were so, the temptation would always be there to desire the insured event and thus to obtain the policy proceeds. ${ }^{12}$

Under the Peshawar High Court scheme, the grandchildren would be benefited more if their parents predecease their grandfather. Now they shall get the whole of their parent's share, which they would otherwise have to

\footnotetext{
${ }^{8}$ Ibid, p. 103

${ }^{9}$ Lucy Carroll, 'Divorce and Succession - Some Recent Cases from Pakistan', Islamic CLQ 4 (1984): 249-50

${ }^{10}$ Supra Note 7, p. 101

${ }^{11}$ Ibid, p. 104

${ }^{12}$ MC Kuchchal, Mercantile Law, $6^{\text {th }}$ Edition, Vikas Publishing House Pvt. Ltd, Lucknow, 2006, p. 438
} 
share with other heirs of their parents like the case of Zarina Jan above. The sole spirit of shariah is to ensure the sanctity of life of the propositus. That is why there is no vested right recognized in Islam and a murderer is excluded from inheritance. Who knows due to the interpretation of Peshawar High Court, now a daughter would wish her parents predecease her grandparents!

Secondly, what section 4 aims at is justice for the otherwise excluded and destitute orphans. Justice will be done if they are substituted in the position in which they would have been had their parent survived. To do justice to the orphans we cannot do injustice towards others. Say for example, the case of a widow whose husband died before her father-in-law. Now her sons and daughters would get whole of her husbands share in exclusion of her. Had her husband not died before her father-in-law, she would have a share in her husband's estate. Who shall do justice to her?

\section{In Lieu of Conclusion}

Bangladesh inherited, with many other laws, the Muslim Family Laws Ordinance, 1961 from Pakistan with the controversial provision in Section 4. Although no one, unlike the cases in Pakistan, has challenged this section, ${ }^{13}$ the question - whether the change brought by the section is justified or not should not go unexamined and unanswered. I think Bangladesh should amend Section 4 of MLFO to address the per stripes succession from its right perspective.

\footnotetext{
${ }^{13}$ The sole Bangladeshi reference relating to Section 4 of the MFLO, 1961 is Sheikh Ibrahim v. Nazma Begum 44 DLR (AD) 276 where the question of operation of Section 4 in case of death of the propositus before or after the coming into force of the Ordinance was answered.
} 